\title{
ESÉLYEK ÉS KÉNYSZEREK. TERMELŐI STRATÉGIÁK ÉS KOOPERÁCIÓS TÖREKVÉSEK A KÖZÉP-MAGYARORSZÁGI RÉGIÓ ZÖLDSÉG- ÉS GYÜMÖLCSÁGAZATÁBAN
}

(Chances and Forces. Produktion Strategies and Co-operation Efforts in the Sector of Fruits and Vegetables in the Central Hungarian Region)

\author{
HAMAR ANNA - RÁCZ KATA - \\ VÁRADI MONIKA MÁRIA
}

\begin{abstract}
Kulcsszavak:
zöldség-és gyümölcságazat Közép-magyarországi régió termelői stratégiák integráció kooperáció

A szerzök tanulmányukban a Közép-magyarországi régió példáján azt a kérdéskört járják körül, hogy a zöldség- és gyümölcságazatban müködö gazdálkodók: östermelök, egyéni, családi és társas vállalkozások, termelöi csoportok milyen értékesitési stratégiákat követnek a radikálisan átrendezödött piacon, mennyire képesek alkalmazkodni az új feltételekhez, továbbá, hogy milyen tényezők támogatják, illetve gátolják a termelök alulról szervezödö, önkéntes szervezeteinek megalakulását és müködését.
\end{abstract}

\section{Bevezetés}

A zöldség- és gyümölcspiacon alapvető átrendeződés indult el a kilencvenes években. A korábban szinte egyeduralkodó nagybani piacok mellett megjelentek és mind nagyobb jelentőségre tesznek szert az áruházláncok, amelyek mennyiségi és minőségi elvárásaikkal, üzletpolitikájukkal a termelőket bejáratott piaci stratégiájuk átgondolására és átalakítására kényszerítik. Átstrukturálódott a zöldség- és gyümölcs export piaca, a biztosnak látszó, és jószerivel mindent fölvásárló keleti piac összeomlása után Nyugat-Európa vált a meghatározó felvevő piaccá, ahol azonban a minőségi elvárásokon túl a magyarországi termelőknek azzal is szembe kell néznie, hogy nem csupán az Európai Unió, hanem a szomszédos közép-, kelet- és déleurópai országok is versenytársaik. A közeledő uniós csatlakozás fényében különösen élesen látszik, hogy a tőkehiány következtében elmaradó beruházások, fejlesztések jelentős versenyhátrányt jelentenek az ország, s így a régió termelöi számára is. Az agrártárca a kis- és közepes termelőket, vállalkozásokat sújtó tőkehiány leküzdésének egyik eszközeként támogatja e termelői kör integrációját, az uniós csatlakozásra való fölkészülés jegyében pedig ösztönzi a termelők önkéntes, alulról szerveződő társulásainak - a zöldség- és gyümölcságazatban az ún. termelöi, értékesítő szervezetek (TÉSZ) - megalakítását.

Tanulmányunkban azt a kérdéskört járjuk körül, hogy a zöldség- és gyümölcságazatban müködő gazdálkodók: őstermelők, egyéni, családi és társas vállalkozások, termelöi csoportok milyen értékesítési stratégiákat követnek a radikálisan átrendeződött piacon, mennyire képesek alkalmazkodni az új feltételekhez, továbbá, hogy 
milyen tényezők támogatják, illetve gátolják a termelők alulról szerveződő, önkéntes szervezeteinek megalakulását és müködését. Tanulmányunk alapját egy, a Közép-magyarországi régió számára kidolgozott program ${ }^{1}$ során az ágazatban müködő termelökkel, integrátorokkal, és az újonnan szervezett szövetkezetek képviselőivel készített 57 interjú képezi.

\section{A zöldség- gyümölcságazat a Közép-magyarországi régióban}

\section{Munició és erőtér}

Noha a Közép-magyarországi régió is az ország azon térségeihez sorolható, ahol a gazdaság más ágainak gyors regenerálódása és az új gazdaságszerkezet kiépülése következtében az agrárgazdaság szerepe viszonylag csekélynek mondható (Kovács Cs. et all 1998), Kovács Katalin elemzéséböl (2001) tudjuk, hogy az ágazat teljesítőképességét jelző egyes mutatók tekintetében - mezőgazdasági GDP, mezőgazdasági beruházások, külföldi tulajdon aránya, export árbevétel nagysága - előkelő helyet foglal el a régiók között. Ami a zöldség- és gyümölcságazat régiós jelentőségét illeti, bizonyos kertészeti termékek - burgonya, gyökérzöldségek, uborka, paradicsom - jelentős részét, vagy éppen többségét (fejes káposzta) a régió, pontosabban Pest megye termelői állítják elő gazdaságaikban; s az ország termő gyümölcsültetvényeinek 13\%-a is a Közép-magyarországi régióban található (Kovács K. 2001) ${ }^{2}$. A régió zöldség- és gyümölcskertészetének termelése az egyes települések, illetve tájkörzetek között természetesen nem egyenletesen oszlik meg; az intenzív zöldség- és virágkertész falvak a főváros szomszédságában illetve a Csepelszigeten, a Galga-vidéken, Tápióságban, Dabas térségében és Dél-Pest megyében találhatók, a három jelentős gyümölcs termőtáj is koncentráltan helyezkedik el a megyében (Ipoly-menti bogyós gyümölcs, Dél-Pest megyei csonthéjas és Budavidéki hagyományos őszibarack termőtáj). A kertész árutermelő falvakban és a gyümölcstermesztési körzetekben egyaránt hosszú évtizedek óta élö, hagyományos kultúrákról beszélhetünk. A Közép-magyarországi régióban zajló markáns tér- és társadalomformáló népmozgalmi folyamatok, kitüntetetten a területfaló szuburbanizáció azonban komolyan veszélyeztetik a főváros közelében húzódó mezőgazdasági területeket, mindenekelött a Buda-vidéki gyümölcs termőtájat, de éppen így az észak-keleti agglomeráció falvaiban még föllelhető termő „,szigeteket” is. A Régió agrárgazdaságának egyik megkülönböztető vonása - a változatos agrárökológiai potenciál és táji adottságok mellett - éppen az, hogy egyes térségeiben „az agrártermelésnek önmagán túlmutató jelentősége van”, az agglomerációs gyürüben a tájfenntartó, multifunkcionális mezőgazdaság megteremtése egyúttal a zöld színek és funkciók megtartásának lehetőségét és feltételét jelenti (Kovács K. 2001).

A Közép-magyarországi régió zöldség- és gyümölcságazatának jelentőségét és fennmaradását legalább két, egymással szorosan összefüggő és egymást feltételező tényező indokolja. Elsőként is a sajátos szerkezet: a régió részét alkotja Budapest és népességét folyamatosan növelő agglomerációja -, az ország legnagyobb fo- 
gyasztói és közvetítő piaca. Ez a tény már a 19-20. század fordulóján is elősegítette az intenzív árutermelő gazdálkodás kibontakozását a fövárost övező kertész falvak gyürüjében (Alsónémedi, Bugyi, Vecsés, Fót, Csomád) és Pest megye zöldség- és gyümölcstermő tájkörzeteiben (Galga-vidék, Tápióság, Homokhátság, Buda-vidék, Ipoly-mente). A jelentős piac ellátására specializálódott friss zöldség- és gyümölcstermelés fennmaradása továbbá azzal a körülménnyel magyarázható, hogy a szocialista agrárgazdaság évtizedeiben a zöldségtermesztés, a nagy- és kisüzemi kooperáció valamely formájában - a részesműveléstöl a szakszövetkezetig - lényegében a magángazdálkodás keretein belül maradt, és a nagyüzemeken belül szerveződő gyümölcstermesztésben is megjelent a nyolcvanas években az ültetvények magántulajdonát lehetővé tevő szakcsoporti forma. A rendszerváltást megelőző évtizedekben tehát fönnmaradtak a régió kertészeti hagyományai, az ágazatban jelentős szakmai tudás, piaci tapasztalat halmozódott fel: ez volt az a muníció, amellyel a termelők nekivághattak a kilencvenes éveknek.

A földtulajdon rendezése és a szövetkezeti átalakulás az ágazat termelöinek egy része számára, a föld és az eszközállomány gyarapítása révén, lehetőséget kínált a termelés szerkezetének átalakítására és/vagy volumenének növelésére; bejáratott piaci kapcsolatokkal, kiemelkedő szakmai tudással jellemezhető kertészvállalkozók, valamint nagyüzemekben dolgozó, magasan kvalifikált és vezető pozícióban lévő, kiterjedt kapcsolatrendszerrel bíró szakértelmiségiek vállalkozásai erősödtek meg, váltak az ágazat sikeres szereplőivé. Némelyikük a szélesebb termelöi kör integrációját is megkezdte a kilencvenes évek végén. A kertészeti kultúra és a termelői kör bázisát alkotó kisebb gazdaságok döntő többsége azonban nem tudta bőviteni területét, és változatlan kapacitással termel a megszokott piacokra, különösen ott, ahol a termékszerkezet a konzervipar igényeinek megfelelően alakult ki (Dél-Pest megye, Galga-vidék, Tápióság). Ezt a termelői kört minden piaci változás, áringadozás igen érzékenyen érinti, úgy igyekeznek talpon maradni, hogy a mindenkor kedvezőbb értékesítési lehetőségekkel kecsegtető árufajtákra térnek át. Arra már ritkábban találunk példát, hogy - egy-egy innovatív kertész kezdeményezésére - új, ismeretlen árufajtákkal kísérletezzenek a termelők (ilyen a brokkoli Dabas térségében, a zöldborsó a Galga-vidéken, az olajtök Püspökhatvanban és környékén), vagy maguk próbálkozzanak saját termékeik feldolgozásával (savanyításával). E termelői kör tagjai ugyan rugalmasságnak és innovációs készségnek nincsenek híjával, ám tőke, elegendő földterület és kapacitások hiányában nem képesek specializált - pl. hajtatásos fóliás - gazdaságok kialakítására, ahogy arra sem, hogy szélesebb termékskálát kialakítva próbálják kiegyenlíteni az egyes fajták áringadozásából fakadó veszteségeiket. Ahol pedig a hajtatásos zöldség (paradicsom, uborka) termesztésére specializálódtak a vállalkozó kertészetek, ott a továbblépést, a termelési technológia és kapacitások minőségi fejlesztését, az egységes fajta illetve minöség szerinti termelés kiépitését gátolja a tőkehiány és a termelők együttmüködése ellenében ható bizalmatlanság. 


\section{Piaci stratégiák és praktikák}

Abban, hogy a termelők milyen értékesítési stratégiákat követnek, a piaci igényeken túl az áru mennyisége, minősége, jellege, a helyi hagyományok fönnmaradása, a bejáratott piaci kapcsolatok éppen akkora szerepet játszanak, mint az ország legjelentősebb fogyasztói és közvetítő piacának, a multinacionális áruházláncok disztribúciós központjainak, a jelentős export-kereskedelemmel foglalkozó cégek közelségéből fakadó mozgástér, és a piac átrendeződésével megjelenő mennyiségi és minőségi követelmények ösztönző/kényszerítő ereje.

A termelö és a fogyasztó közvetlen kapcsolatán alapuló értékesités, mindenekelőtt a városellátó termelés hagyományos kereteihez illeszkedve, ma is eleven és jelentős a régióban. Elsősorban a kisebb volumenben, ház körüli kertekben, zártkertekben megtermelt termékek kerülnek értékesítésre Budapest vagy más városok, körzetközpontok kispiacain, a közvetlen piaci értékesítés azonban átnyúlik a megyehatárokon is ${ }^{3}$. Pest megye egyes vidékein, leginkább a Galga-mentén, különösen erősek a kofás kereskedelem hagyományai, a Zsámbéki-medence csonthéjas gyümölcsültetvényeiről a magántermelők többsége a közeli Fény utcai, vagy a Lehel téri piacra hordta/hordja áruját. A hagyományos piacozó termékértékesítés keretei azonban megváltoztak a nagyobb budapesti piacok (Fény utca, Lehel tér) átalakításával, amelynek köszönhetően a kisebb 'kofás' kereskedők kiszorulnak a kétségtelenül rendezettebb és kulturáltabb, ám jóval költségesebb és így számukra nehezebben elérhető csarnokokból; a hagyományos 'kofás' kiskereskedelem azonban töretlenül müködik tovább a kerületi kispiacokon. A termelö és fogyasztó közötti közvetlen értékesítés más formája is megtalálható a régióban. A friss, esetleg feldolgozott termékek háztól való értékesitése elterjedt, s ugyan individuális és koordinálatlan, de fejlődésre ítéltetett tevékenység. Megjelentek ugyanis olyan városi és városkörnyéki szuburb településeken élö, fizetőképes fogyasztói csoportok, amelyek egészséges (nem feltétlenül bio) termékeket keresnek, és ezeket szívesen veszik (vennék) meg közvetlenül a termelötől.

A régió jelentősebb zöldségtermesztő vállalkozói termékeik többségét (vagy egészét) a Budapesti Nagybani Piacon értékesítik, és a nagyobb gyümölcsültetvényekről is ide hozzák az export után megmaradt jó minőségü, friss fogyasztásra szánt termést. Ha a termelőket kérdezzük, a nagybani piac megítélésében a mérleg a negatívumok oldalára billen: a piac kiszámíthatatlanságára, az árak ingadozására, az olcsó import termékek árletörő hatására, mindenekelőtt azonban a kereskedőknek való kiszolgáltatottságra panaszkodnak. Ugyanakkor többségük nem csupán egyéb lehetőségek híján ragaszkodik a nagybani piachoz, mint elsődleges értékesítési csatornához. A jelentősebb, jó minőségü áruval megjelenő termelők ugyanis az évek alatt kialakult, megbízható kapcsolatokra tettek szert a 'nagybanin', termékeiket állandó partnerek vásárolják meg. Nagyobb súllyal esik azonban a latba, hogy $a$ nagybani piacon zajló forgalom túlnyomórészt - becslések szerint 80\%-ban - 'feketén', vagyis számla nélkül bonyolódik, a termelö így adóterhekkel nem sújtott, tiszta 
jövedelemre tesz szert. A nagybani piac hátrányai és előnyei így a termelő érdekei felől nézve, végső soron kiegyenlítődnek.

A kertész vállalkozók egy része törekszik arra, hogy lazítson a nagybani piactól való függőségén, illetve, hogy mentesüljön a nagybani piacozással járó fáradtságtól és költségektől, és más értékesítési csatornákat keres, pl. helyi kiskereskedelmi üzleteket, regionális piacokat ${ }^{4}$, vagy éppen export-piacokra vagy az áruházláncokba szeretne beszállítani - s ez utóbbiak jelentik a legnagyobb kihívást számukra. Az ágazatban a termelök jellemzö értékesitési stratégiája ugyanakkor, hogy nem 'kötik gúzsba' magukat (tehát óvakodnak attól, hogy egyértelmủen elkötelezzék magukat), és az aktuálisan legjobban fizetö (vagy annak tünö) piacon igyekeznek eladni termékeiket. Más szavakkal: a jellemző piaci stratégia alapelve a rugalmasság és a több lábon állásra való törekvés. Minél nagyobb és erősebb egy gazdálkodó vagy vállalkozás, annál nagyobb mozgástere nyílik e piaci stratégia érvényesítésére.

A gyümölcságazatból hozott példával élve: a megye csonthéjas és alma termőtájain a termelők piaci stratégiái az ültetvények nagyságától, a tulajdonosok kooperációs hajlandóságától és tőkeerejétől függenek. A kisebb egyéni gazdaságokból és a volt szakcsoporti, jelenleg egyesületi vagy szövetkezeti keretekben müvelt ültetvényekről egyénileg értékesítenek a termelők, kiskereskedelmi üzleteknek, a nagybanin, vagy kispiacokon, esetleg az ültetvényekről adják el a termést a kereskedőknek (a Zsámbéki-medence csonthéjas ültetvényein és Dél-Pest megye Ceglédnagykőrösi alkörzetben domináns stratégia). A nagy ültetvények a szövetkezeti, állami gazdasági utódszervezetek kezelésében maradtak és/vagy legalább részben a hajdani nagyüzemi szakemberek tulajdonába kerültek. Ez a tulajdonosi kör sikerrel törekedett különféle kooperációs formák kialakítására, ami nem pusztán a kívánt minőség biztosításához elengedhetetlen szakmai felügyeletet biztosítja számukra, hanem kedvező piaci pozícióik megtartásához is hozzájárult (Dél-Buda vidéki csonthéjas termőtáj, Dél-Pest megye Dánszentmiklós-berceli alkörzet). Ezen ültetvények tulajdonosai áruházláncokkal, illetve azok disztribútoraival, valamint feldolgozó-ipari cégekkel állnak kapcsolatban, és gyakran termékeik 30-40\%-át is külföldi piacokon értékesítik. Nem ritkán saját, exporttevékenységet folytató vállalkozást alapítottak, amely az exportra értékesített termékek 20-30\%-ában lehetővé teszi a közvetlen beszállítást, kihagyva az értékesítési láncból a 8-10\%-os hasznot lefölöző közvetítőt.

Az export-piacra közvetlenül, vagy közvetve szállító termelők, kisebb felvásárlókereskedő cégek szerint e piacon az éles verseny okozza a legnagyobb bizonytalanságot - a külföldi áruházláncok például hetente határozzák meg a felvásárlási árakat. $^{5}$ A közvetlen export kevesek számára elérhető tevékenység, hisz a külföldi partnerek ragaszkodnak a már ismert közvetítő kereskedelmi cégekhez. Egy jelentős ültetvénnyel és termésmennyiséggel rendelkező vállalkozó szerint a hajdani egyetlen nagy export-cég helyén ma 8-10 exportőr konkurál egymással, ami „átláthatatlanná teszi a piacot, így nincs egy másodpercnyi biztonság sem”. Bármilyen éles azonban a verseny a nyugat-európai piacon, a külföldi piaci partnerek pontosan, és föként jóval rövidebb időn belül fizetnek, mint a magyarországi nagy áru- 
házláncok, és a beszállítót nem terhelik olyan költségek, mint a listán maradási pénz, a polcpénz, a reklámokhoz való hozzájárulás és az akciókban való kötelező részvétel.

A kereskedelmi láncok megjelenése jelentette az egyik legdöntőbb változást az élelmiszerpiacon a kilencvenes években. A folyamatos, jó minőségü és nagy menynyiségü beszállítást megkövetelő láncokba, amelyek egyre jelentősebb részt hasítanak maguknak a zöldség-gyümölcspiacon, egyénileg szinte lehetetlen bejutni. Azok a termelők tudtak e piacon megjelenni, akik időben, a kilencvenes évek elején építették ki új kapcsolataikat (az akkor alakulóban lévő áruházláncoknál), a földtulajdon rendezése és a termelőszövetkezetek átalakulása során növelni tudták termelöi és háttérkapacitásaikat, vagy átmentve a korábban monopolhelyzetet élvező állami kereskedelmi cégek vezetőivel kialakított kapcsolataikat, biztos piacot találtak termékeiknek. Jellemző e vállalkozásokra, hogy magas hozzáadott értékü árut szállítanak kereskedő partnereiknek (pl. előcsomagolt, tisztított zöldség), és/vagy felvásárlással is foglalkoznak. Az áruházláncok mégis a nagy beszállítókkal állnak szívesen szóba, így az áru többszörös közvetítéssel jut a termelőtől a kisebb felvásárlón át a nagyobb felvásárló-beszállítóig. A termelők, kisebb integrátorok, felvásárlók már csak azért sem lennének képesek közvetlen beszállítókká válni, mert a késedelmes, minimum harminc napos fizetési határidő miatt a beszállítónak igen jelentős forgótőkével kell rendelkeznie ahhoz, hogy ezt az időszakot átvészelje.

A termelők kénytelenek voltak felismerni, hogy erre a növekvő jelentőségü piaci szegmensre csakis úgy tudnak belépni, ha egymással kooperálva olyan árualapot hoznak létre, amely mind mennyiségénél, mind minőségénél fogva megfelelő alkupozíciót biztosít számukra. Az áruházláncok megjelenése tehát kényszeritő erőt jelent, amely a termelőket az egymással való kooperációra ösztönzi. A kereskedelmi láncokkal kapcsolatba kerülö termelők és beszállítók ugyanakkor nagyon határozottan fogalmazzák meg azt a véleményüket, hogy az áruházláncoknál végső soron nem a beszállitott áru minősége játssza a döntö szerepet, hanem az ár; az maradhat tartósan az áruházláncok partnere, aki olcsóbb termékeket kínál.

A termelők döntő többsége közvetlenül sem az export-piacokra, sem az áruházláncok bővülő piacára nem tud belépni, és elegendő mozgástérrel sem rendelkezik ahhoz, hogy a több lábon álló, rugalmas értékesítési stratégiát kövesse, így rá van utalva a piac legfontosabb szereplöire, azon termelö, kereskedelmi vállalkozásokra, feldolgozó-ipari cégekre, amelyek a régió termőhelyein müködnek felvásárlóként vagy integrátorként.

\section{Közelképek az 'integrációról'}

Abban, hogy az agrárgazdaságban az átfogó tőkehiány mellett a hajdani - jól vagy rosszul, ellentmondásokkal terhelten, de müködő - integráció szétesése jelenti a legnagyobb, mindenekelőtt a családi gazdaságokat sújtó problémát, a szakértők széles köre egyetérteni látszik. Ezért (is) tartják indokoltnak az ágazat strukturális átalakulását elősegítő intézkedések között a korszerü vertikális együttműködési 
láncok (vertikális integráció) kialakulását, a korszerü kooperációs formák állami támogatását (Juhász-Mohácsi 1995). Az elemzések a hajdani szövetkezeti integráció radikális mértékü visszaszorulásáról számolnak be, illetve arról, hogy noha az átalakult szövetkezetek szívesen integrálnák a kisebb termelőket, azok az integrátori szolgáltatásokat nem tudják megfizetni (Tóth-Varga 1997). Az integráció biztonságot jelent az integrált gazdaságoknak, amelyekben a termelés visszaesése nem volt akkora mértékü, mint az agrárgazdaság egészében (Kapronczai 1996), az új integrációs rendszereket azonban kritikával is illetik; a termelők integrátorokkal szembeni kiszolgáltatottságát, az integrátor monopolhelyzetét tartják a legnagyobb gondnak, véleményük szerint az integrációs rendszer lényegében nem más, mint a „lefölözések rendszere” (Hantó 1996). ${ }^{6}$ Az integráció varázsszavához különböző tartalmak kapcsolódnak; a kis családi gazdaságoknak nyújtott nagyüzemi szolgáltatásokat éppen úgy jelenti, mint a termeléstől a feldolgozáson át az értékesítésig húzódó vertikum kiépítését egy üzemen/vállalatcsoporton belül. Az integráció döntő eleme azonban az, hogy a kisebb termelöket tőkeerős vállalkozások közvetítésével juttatja a termeléshez/müködéshez elengedhetetlenül szükséges forrásokhoz, amelyekhez az integrált üzemek magukban nem férhetnének hozzá.

Az integráció, az integrátori tevékenység célja az integrált mezőgazdasági kis- és középvállalkozások versenyképességének növelése, a jövedelmező termelési szerkezet és méret kialakítása, a piacra jutási esélyek javítása, az uniós normák adaptálása, valamint az integrált kis- és középvállalkozások számára támogatások és kedvezmények közvetítése. ${ }^{7}$ Az írásban rögzített integrátori szerződés keretein belül az integrátor biztosítja a termelő számára a termelési technológiát, a vegyszert, vetőmagot, szaktanácsadást, a termékek felvásárlását, továbbá állami támogatásokat közvetít. A termelőknek az integrátori rendszer a korszerü technológiák megismerését, a termelés (legalább részleges) előfinanszírozását és az értékesítés biztonságát jelenti. Az integrátori tevékenységet végző vállalkozás nyeresége egyrészt az, hogy stabilizálni tudja piaci pozícióját az egységes, minőségi követelményeknek megfelelő árualap bővítésével, másrészt, hogy az állami támogatás révén pótlólagos forgóeszközzel gazdálkodhat.

2001 nyarán Budapesten és Pest megyében összesen 109 bejegyzett integrátort tartottak nyilván, amelyek elsősorban a szántóföldi növénytermesztés és az állattenyésztés területén integráltak termelöket, szövetkezeteket, gazdasági társaságokat és többségében őstermelőket. Zöldség- és gyümölcstermesztők integrációjával 23 cég foglalkozik. ${ }^{8}$ A Közép-magyarországi régióban, a zöldség-gyümölcs ágazatban integrátori tevékenységet folytató cégek száma viszonylag alacsony, s a helyzet még kedvezőtlenebb, ha figyelembe vesszük, hogy az integrátorként számon tartott ágazati szereplök között akad egy-kettő, amelyik fölhagyott korábbi integrátori tevékenységével, vagy csak papíron, az 1998-as beruházási hitelek megszerzése érdekében végzett ilyen tevékenységet. Az alábbiakban az integráció néhány régiós modelljét kívánjuk bemutatni. 


\section{Kötöttségek: a lokális integráció egy példája}

A chips-nek való ipari burgonya termelésének integrálása 1995-ben vette kezdetét Bugyin. Ebben az évben egy multinacionális cég, a Pepsi a lengyelországi és magyarországi üzemeiben folyó gyártáshoz keresett sziromnak való korai krumplit termesztő szövetkezetet Magyarországon, hogy a lengyel burgonya beéréséig kiváltsa a dél-európai országok termelőitől a szállítási költségek okán jóval drágábban beszerezhető alapanyagot. Abban, hogy a cég választása éppen Bugyira esett, a kedvező közlekedés-földrajzi pozíció mellett nagy súllyal esett a latba a korai burgonya hagyományos termelési kultúrája, a termelök szaktudása, a szövetkezeti infrastruktúra. A Pepsi egyik angol vezetőjének irányításával hatvan hektáron elindított próbatermelés beváltotta a reményeket, így a cég és a Tessedik Sámuel Szövetkezet megkötötte első, ötéves szerződését. A bugyii esetben az integráló szövetkezet közvetítő szerepet játszik a termelök és a multinacionális cég között, amely biztosítja a speciális import vetőburgonyát, a termesztési technológiát, a folyamatos ellenőrzést szaktanácsadással köti egyben. A cég a magyar szakembergárdát oktatásban részesítette, $\mathrm{s}$ a speciális betakarító gépeket is a termelők rendelkezésére bocsátotta.

A szövetkezet évente újra megköti a szerződést a termelőkkel, akiknek száma az induló nyolcvanról hat év alatt hatvanra apadt, s noha várható a további csökkenés, a 250 hektáros terület legalább ötven gazdálkodó számára biztosít majd jövedelmet. Az integrált termelői körbe való bekerüléshez szükséges belépőt az öntözés biztosítása és a megfelelő talaj-előkészítés jelentette, 2001-től a vizsgálati jegyzőkönyvvel igazolt fonálféreg-mentesség is megjelent a követelmények között. A további korlátozások a szövetkezetként müködő utódszervezet tulajdoni és szervezeti bizonytalanságával függnek össze. A menedzsment - amely az üzletrészek intenzív fölvásárlásának köszönhetően sikerrel koncentrálta a vagyont, így annak 70\%-a osztatlan közös tulajdonba került -, ma még nem látja az átalakulás mikéntjét, az azonban bizonyos, hogy a szövetkezeti átalakulás újabb grádicsa következik. A folyamat érinti az integrált termelői kört is, amelynek, a menedzsment szándéka szerint, úgy kell biztosítania a 250 hektáros terület müveléséhez szükséges vagyon fedezetét, hogy önálló vagyoncsoportot hoz létre. Ennek érdekében a szövetkezetben tulajdonos integrált termelök bennhagynak, a szövetkezethez tulajdonosként nem kapcsolódó gazdálkodók pedig vásárolnak százezer forintnyi üzletrészt. A szövetkezet átalakítását tervező menedzsment politikája, mintegy véletlenül, megfelel az integráló multinacionális cég érdekeinek, hiszen a felvevő piac kötött, a lengyel és magyar chips-elöállító üzemek alapanyag-igénye, ahogy eddig, úgy várhatóan ezután sem növekszik, s ez a tény az integrációban résztvevők körének csökkenését eredményezi.

\section{Integrációs kényszer egy 'sikerágazatban'}

Az étkezési gomba (champignon és kisebb mértékben a laska) termesztés méltán nevezhető az ország, egyben azonban a Közép-magyarországi régió kertészeti sikerágazatának. Az étkezési gomba termelési volumene és exportpiaci súlya az 
elmúlt évtizedben példátlan mértékben növekedett ${ }^{9}$. A Közép-magyarországi régió - $s$ azon belül is Budapest - termelöi állítják elö az országban termesztett gomba 45\%-át; a budai kerületekben a becslések szerint közel 500 ezer négyzetméternyi, mészkőbe épített pinceterület található. Tökön és Áporkán épült meg az a két komposztüzem, amely az ország komposzttermelésének felét biztosítja.

A hagyományos keleti piacok eltünése, az exporttal összefüggő minőségi követelmények, a fejlesztésekhez szükséges tőke hiánya okán ma feleannyian foglalkoznak gombatermesztéssel, mint tíz évvel ezelött. Ma már csak az a gazdaság maradhat talpon, amelyik legalább 3000 négyzetméternyi termőfelülettel, valamint a termesztés folyamatosságát biztosító technológia beállításához, illetve a termesztés és értékesítés finanszírozásához szükséges tőkével rendelkezik. A talpon maradt, megfelelő szaktudással rendelkező termelők beszállitóként vagy integrált termelőként kapcsolódnak a Közép-magyarországi régióban müködö hat vezetö vállalkozáshoz, amelyek közül öt önálló termelést is folytat.

A Közép-magyarországi régió legnagyobb integrátora a Champignon Union Kft.; a jelentős tőkeerejü cég nem csupán a régióban, hanem az ország más fontos termőhelyein, Győr és Pécs környékén, valamint Nógrád megyében is integrál, száz termelővel áll kapcsolatban. A vállalkozás a termelőknek eladott komposzt fejében, szerződésben rögzített keretek között, vállalja, hogy a termelő várható termésmenynyiségének a felét átveszi; azért számítanak csak a megtermelt alapanyag felére, mert a vállalkozás egyik vezetője szerint „egy termelő nem csak egy nagyobb céghez kötödik, nem is teheti meg, mert akkor tönkremenne”. A vállalkozás szaktanácsadást biztosít, és annak, aki saját kapacitások hiányában erre rászorul, gombatermesztésre alkalmas pincét bérel, a megbízható, folyamatosan jó minőségü árut időben szállító, és a gombát kis kiszerelésű dobozokba csomagoló termelőknek pedig $10 \%$ jutalékot fizet.

Miért fontos az integráció a gombaágazatban, túl azon, hogy a termelők biztonságát és az egységes, jó minőségű árualap előállítását szolgálja? Az ágazat versenyképességét veszélyezteti, hogy miközben az alapanyag-előállításba jelentős tőkét invesztáltak, elmaradtak a technológiai korszerüsitések. A nyugati országokban az étkezési gombát felszíni, holland rendszerü termesztő házakban (gombaházak), vagy duplafalú (Richel) gombasátrakban termesztik, ez a technológia lehetővé teszi a termőfelület jelentős növelését. A fővárosi pincék egyre kevésbé felelnek meg a minőségi követelményeknek, többségük arra sem alkalmas, hogy a hagyományos zsákos termesztést felváltó új technológiát telepítsenek benne. A gombaházak, gombasátrak létesítése igen nagy költségigényü (egy ötsoros, háromszintes termesztő ház költsége 300 millió Ft), ugyanakkor az agrártámogatási célok között 2001-ben jelent meg először a gombatermesztés technológiai megújításához kötődő beruházások támogatása. Nyilvánvaló, hogy a kisebb termelök képtelenek egy ilyen volumenü fejlesztés megfinanszirozására, erre csak integrátorokon keresztül nyilik lehetöségük ${ }^{10}$. 


\section{Akadozó integráció egy veszélyeztetett ágazatban}

Az Ipoly-környéki bogyós gyümölcstermelő tájkörzet a magyarországi málnatermelés negyedét, a ribizli termelés több mint egyharmadát biztosítja, a Középmagyarországi régióban található az ország legkoncentráltabb bogyós gyümölcstermesztési körzete ${ }^{11}$, melyet azonban több veszély is fenyeget. Az új telepítéseket és a kézi munkát kiváltó gépek beszerzését akadályozó tőkehiány, a bogyós gyümölcstermesztés növekvő mértékü jövedelem-kiegészítő szerepe, valamint a termelők ragaszkodása a termesztés hagyományos, az ültetvény méretét a család munkaerejéhez méretező kereteihez (Bali 1998) egyaránt azt eredményezi, hogy a parcellákra szakadozott, amortizálódó hajdani nagyüzemi ültetvények helyén nem alakultak ki gazdaságos üzemi méretü korszerü ültetvények ${ }^{12}$.

A tájkörzet termelöit rendkívül erősen sújtja a szövetkezeti integráció megszünése, a vertikum szétesése. A hajdan biztos felvevő piacot jelentő feldolgozó és hütő kapacitások tönkrementek, vagy eladták őket, a termőtáj Pest megyei területén csupán két hütőház müködik (Bernecebaráti, Kemence). A francia tulajdonba került szobi lé-feldolgozó alapanyagát döntően külföldről szerzi be, Dunakeszin megszűnt a feldolgozás, a győri ARVIT tulajdonába került hütőház elsősorban bérhütést végez. A térségben felvásárlóként jelen vannak az ország legjelentősebb feldolgozó üzemei és kereskedő cégei, mellettük a semmiböl felbukkannak az ismeretlen, ki tudja, milyen cégnek felvásárló kereskedők. A gyümölcs fölvásárlása több közvetítőn keresztül történik - a cégek helyi vagy más felvásárlókat bíznak meg -, a szezon kezdetekor a felvásárlók árkartellel szorítják le az árakat, az egymással kooperálni nem hajlandó termelők pedig képtelenek az egységes fellépésre ${ }^{13}$. A termelők a bogyós gyümölcstermesztés jövedelmezőségének romlásáról panaszkodnak; amin a szakértők szerint - mivel a kereslet bővülése nem várható - csak a korszerü fajtaszerkezet kialakítása javíthatna. A termelők szerint viszont, ha minőségi fajták telepítésére vállalkoznak, a kisebb terméshozamú ültetvényeken termett gyümölcsért a felvásárlók nem fizetnek arányos árat, s ez a fajtaváltás ellen hat.

A szerkezetváltás mégis szükségszerü, a telepitések magas tökeigénye miatt viszont csak integrátoron keresztül (lenne) lehetséges. A térség ültetvényterületéhez képest elenyésző az integrált gazdaságok nagysága. A Bakos Hütőipari Rt. az egyetlen integrátor az Ipoly-mentén, kétféle integrációs formát müködtet, amely összesen mintegy 50 családot érint; biztosítja az ültetvény ápolásához (metszés) szükséges forgótőkét (összesen 43 hektáron), illetve 2000-ben 17 hektár málna vírusmentes szaporítóanyagát, a kerítést és a támrendszert finanszírozta meg. A Hütőháznak a ribizli integrációjára tett kísérlete zátonyra futott a termelők megosztottsága okán, s mert néhányan közülük más feldolgozók számára végeznek felvásárlást; a Hủtőház így maga kezdett ültetvény telepítésébe. A bogyós gyümölcstermesztésben a telepítés és a müvelés folyamatosan emelkedő költségei, a termelők piaci kiszolgáltatottsága ellenére sem a termelői kooperáció, sem az integráció területén nem történt érdemi előrelépés, a hajdani integráció helyén semmi nem jelent meg. 


\section{Változékony integráció: feldolgozók}

A Közép-magyarországi régióban hütőházak (a Dél-Pest megyei Mirsa Rt., Bakos Hűtőház) mellett konzervgyárak (Bonduelle, Nagykőrösi Konzervgyár) is vállalnak integráló tevékenységet, és felvásárlóként is megjelennek a fontos termőhelyeken. A szocializmus évtizedeivel összehasonlítva, amikor mind a Nagykőrösi, mind a Hatvani Konzervgyár döntő szerepet játszott a zöldség- és gyümölcskertészet fennmaradásában, és biztos piacot jelentett nem csupán nagy mennyiségü, de a kevésbé jó minőségű termékek számára is, az integráció volumene és biztonsága töredékére csökkent. Az integráló tevékenység nem minden esetben megyei termelöt érint: a francia tulajdonban lévő Bonduelle a termőhelyi adottságok és az öntözés hiánya miatt más körzetekben építette ki a termeltetés rendszerét. A Nagykőrösi Konzervgyár és a Mirsa Hütőház is döntően a régión kívül szerzi be a feldolgozott árufélék alapanyagát. Lehet, hogy ez is szerepet játszik abban, hogy a térség zöldségtermelő kistermelőinek alkupozíciója nagyon gyenge a feldolgozó cégekkel szemben. Pedig erre nagy szükségük lenne, hiszen évről évre új megszorításokkal kell számolniuk az orosz válság megrázkódtatása után lassan konszolidálódó cégek részéről. A Nagykőrösi Konzervgyár például évről évre kedvezőtlenebb kondíciókkal fizet, s míg korábban a minőség (szárazanyag-tartalom) szerint különböző osztályokba sorolta az árut, s differenciáltan fizetett, addig 2000 óta az átlagminőség bevezetése, a beszállítói időszak lerövidítésével párhuzamosan, kedvezőtlenül érinti a termelöket. Különösen megnehezíti a kertészek helyzetét, hogy a Konzervgyár csak az átvételi ár felét fizeti ki közvetlenül a termelőnek, a másik felét ártámogatásként, magának a termelőnek kell megpályáznia. (Az ártámogatás kifizetését 2000-ben még a gyár bonyolította.) A termelők pedig nem szívesen bíbelődnek a pályázatírással, és ha nem akad valaki, aki segít nekik ebben, akkor inkább elállnak a szerződéskötéstől, illetve más értékesítési lehetőségek után kutatnak.

Új fejlemény a régióban, hogy közvetlenül, vagy felvásárló vállalkozásokon keresztül, megjelentek olyan konzervipari cégek, amelyek eddig az ország más termőhelyein termeltették, illetve szerezték be az alapanyagot. A 15-20 jelentősebb farmosi paradicsomtermelő ma már nem pusztán a Nagykőrösi Konzervgyárral, hanem a Hatvani Konzervgyárral is szerződéses kapcsolatban áll. A Hatvani Konzervgyár szemmel láthatólag igyekszik megvetni a térségben a lábát - ezért is ígér rá jelentősen a nagykőrösiek áraira -, a Tápióságban és a Galga-vidéken igyekszik kialakítani egy új beszállítói kört. A Györ-Moson-Sopron megyei Horker Kft. DélPest megyében vásárolja fel az uborkát, paprikát, miután a hagyományos nyugatmagyarországi tájkörzetben radikális mértékben visszaszorult a kertészeti termelés és az integrált termelöi kör. Az újonnan megjelent cégek hosszabb távon az integráció kialakításában gondolkodnak, s megjelenésük a termelők számára kedvező, mert, legalábbis amíg lábukat megvetik a régióban, magasabb áron veszik át a termést, mint a térségben 'tősgyökeres' felvásárlók. 


\section{A kereskedök és az integráció}

A Közép-magyarországi régió (részben bejegyzett) integrátorai között a legtőkeerösebbek kétségtelenül a kereskedelmi vállalkozások, amelyek belföldi és exportkereskedelemmel egyaránt foglalkoznak, akad közöttük olyan, aki külföldön is termeltet. A nagy feldolgozók, áruházláncok állandó beszállítói e cégek, amelyek az ország termőhelyein, közvetlenül vagy kisebb integrátorok révén, mindenütt kiépítették beszállítói kapcsolataikat, és a megfelelő infrastrukturális beruházásokra is jelentős összegeket fordítottak: jelen vannak Csongrád, Bács-Kiskun, Hajdú-Bihar, Szabolcs-Szatmár, Szolnok, Békés megyében, több hütőtárolóval, raktárbázissal, csomagoló kapacitással rendelkeznek.

E több milliárdos éves forgalmat bonyolító társas vállalkozások nagy számú (néha közel 2000) termelővel állnak kapcsolatban, akiknek döntő többsége nem a Középmagyarországi régióban gazdálkodik. Van olyan vállalkozás, amely korábban kötött integrátori szerződést a termelőkkel, de a cégtulajdonos szerint "nem volt értelme, mert aki nem megbizható, annak az irás ugyanúgy nem jelent kötöttséget, mint a szóbeli megállapodás". Arról is hamar letettek, hogy a termelőket vetőmaggal, forgóeszköz-hitellel támogassák, mert „az a kertész, aki maga nem képes megfinanszírozni saját termelését, a vállalkozás szempontjából nem megbizható, mert az integrátortól kapott pénzt illetve a termékeket arra használja, hogy más hézagokat tömködjön be”. A szóban forgó vállalkozás tehát csupán felvásárol, természetesen nem akárkitől; nem a termésmennyiség a fontos, hanem ,a céggel szembeni megbizhatóság", ami folyamatos és kizárólag a cég felé történő értékesítést jelenti. A „megbízható termelő” jutalma nem is marad el; dömping idején is átveszik tőle áruját, sőt a fölvásárlótól fontos és bizalmas információkat kaphat arról, hogy a fütött fóliában miként ütemezze a különböző növények termesztését, hogy azok jövedelmezők legyenek.

Más vállalkozások részint minden termőhelyen, a mennyiségtől függetlenül felvásárolják a jó minőségű termést, emellett azonban működtetnek egy, kizárólag nagy termelőket (mintegy 100-150 föt) érintő integrációs kört is. A felvásárló-integráló vállalkozás tulajdonosai szemében az a komoly termelö, aki legalább évi tízmilliós forgalmat bonyolít a cég felé. A szóban forgó vállalkozás évente köt a termelőkkel integrátori szerződést, biztosítja a vetőmagot és a fóliát, szükség esetén speciális gépek vásárlását is meghitelezi. Kezdetben mindezeket az áruszállításig meghitelezték a termelőknek, de ma már 50\%-os hitelként nyújtják e szolgáltatásokat a termelők számára, mert „,nem veszik komolyan a termeltetést akkor, ha nekik nincs benne pénzük és saját kockázatuk”.

\section{Látlelet: a termelök, a piac és az integráció}

A termelők, legyen szó bármely értékesítési formáról, a kereskedelmi cégeknek, felvásárlóknak való kiszolgáltatottságról panaszkodnak. Azokban a térségekben Dél-Pest megyében Nagykőrös és környéke -, ahol sokan foglalkoznak kertészeti 
termeléssel, a termelők különböző feldolgozó és kereskedelmi cégek érdekeltségi körébe tartozó felvásárló telepeken értékesíthetik portékájukat, s kihasználhatják a felvásárlók közötti versenyből adódó előnyöket. A verseny azonban korlátozott, mert a kereskedők figyelnek egymásra, nem érdekük a magas árak kialakítása: „, $a$ mobiltelefonok világában" percek kérdése az árkartell kialakítása, módosítása. Ahogy egy kereskedelmi cég alkalmazottja fogalmazott, a kereskedők ,versenytársai, de nem ellenségei egymásnak". A termelők véleménye szerint a feldolgozókkal, felvásárlókkal, áruházláncokkal kötött szerződések sem enyhítik a kiszolgáltatottságot, bizonytalanságot.

A zöldség- gyümölcságazat egészére jellemzö, hogy a szerzödéses kapcsolatok ritkák, és nem jelentenek garanciát, sem a termelö, sem a felvásárló, kereskedő, integrátor számára. A termelők nem szívesen kötelezik el magukat egyetlen értékesítési lehetőség mellett, már csak azért sem, mert a szerződésekben az átvételi árakat a legritkábban rögzítik. Ha pedig erre mégis sor kerül, akkor is gyakran elöfordul, hogy a felvásárló egy nap leforgása alatt módosítja mind a megrendelt mennyiséget, mind az árat. A felvásárlók szerint ebben az ágazatban nem is lehet előre meghatározni az árakat, és a termelök is megbízhatatlanok, a megkötött szerződések ellenére sem szállítják a meghatározott mennyiséget, ha másutt kedvezőbb értékesítési lehetőség kínálkozik, sőt arra is akadt már példa, hogy a termelő a jobban fizető konkurenciának az integrátor göngyölegében adta el a szerződött portékát. A szerződések, ha írásban köttetnek is, a keretfeltételeket tartalmazzák, a minimálisan illetve maximálisan beszállítandó/átveendő árumennyiséget: ha nem is beszélhetünk az ágazatot uraló kölcsönös bizalmatlanságról, tény, hogy a szereplők mindegyike igényli a biztonságot - a termelő kapja meg, amit szeretne, az áru viszont érkezzen meg pontosan a helyére -, de a valamelyest önálló, a kötöttségeken lazító mozgásteret is. A termelők és kereskedők egyaránt azt hangsúlyozzák, hogy a szerződéseknek semmi jelentősége nincs, „a szerződés arra való, hogy megszegjék”, az ágazat piacán a meghatározó szereplőket a személyes kapcsolatokon alapuló bizalom köti össze, ami 'papírtól' független.

Az integráció változatait bemutató esetek legfontosabb tanulsága, hogy a régió termelöi csak korlátozott mértékben kapcsolódhatnak integrációkhoz. A speciális kultúrákhoz kötődő integrációkban a megfelelő termelési technológia és/vagy a fejlesztésekhez szükséges tőke hiánya, a korlátozott piac, a feldolgozó cégek bizonytalan és változékony üzletpolitikája, nem ritkán az integrálóval szembeni bizalmatlanság akadályozza az integrált kör bővülését. A kereskedelmi tevékenységet folytató, tőkeerős integrátorok pedig eleve a jelentős forgalmú, kifejezetten nagy termelökkel kötnek szerződést, a derékhadat alkotó kistermelői bázisnak esélye sincs velük integrációs kapcsolatba lépni. Az integrációs rendszerek tehát a régió zöldség- és gyümölcságazatában fenntartják, felerősítik a termelöi körön belül a piacgazdaságra való áttérés során kialakult különbségeket, s legfeljebb korlátozottan teljesítik a nekik rendelt feladatot: a kistermelöi kör piaci pozíciójának, a termelés és értékesítés biztonságának stabilizálását. 


\section{Termelöi kooperációk a Közép-magyarországi régióban}

A megváltozott piaci feltételek között a termelök egy része a régióban is arra törekszik, hogy a megszokott egyéni értékesítési stratégiák mellett a kooperáció útjait keresse, több termelőt összefogó szervezetet alakítson, megteremtve az összehangolt termelés, a közös értékesítés, feldolgozás és beruházás - azaz egyfajta termelöi integráció - feltételeit. A termelők önkéntes, alulról szerveződő társulásainak alakítását az agrártárca is ösztönzi, a zöldség-gyümölcságazatban az uniós csatlakozásra való felkészülés jegyében az ún. termelői, értékesítő szervezetek (TÉSZ) támogatásával. Az EU-ban a TÉSZ-ek ${ }^{14}$ a termelők közös értékesítésre és feldolgozásra létrehozott nonprofit jellegü piaci szervezetei, amelyeknek természetes és jogi személyek egyaránt tagjai lehetnek. A TÉSZ nem jelent feltétlenül szövetkezeti formát, hiszen, ha megfelel a feltételeknek, bármely jogi személy elismerhető ilyen szervezetként. A TÉSZ-ek az unióban piacszabályozó szerepet töltenek be, a termelők pedig csak akkor jogosultak támogatásra, ha egy ilyen szervezet tagjai. A TÉSZ-ek megalakításának ösztönzése már csak azért is fontos ágazati feladat, mert a termelők az uniós csatlakozást követően csak TÉSZ-tagként juthatnak a támogatásokhoz. Ugyanakkor, s ez a termelők érdekeivel is egybevág, a TÉSZ-ek megalakulását azért is támogatja a kormányzat, mert ezzel (a remények szerint) elérhetővé válik, legalábbis hosszabb távon, a közvetítő kereskedelem kiiktatása, s az, hogy az ott keletkező haszon a termelöknél maradjon.

A TÉSZ-ek megalakításának törvényi feltételei megszülettek, alakulásuk mégis akadozik, részint a megalakítás törvényben rögzített feltételeinek és a támogatási rendszer ellentmondásainak eredményeként ${ }^{15}$, részint azért, mert a termelők számára nem vonzó alternatíva a TÉSZ-hez való csatlakozás. A TÉSZ-ek megalakulása a tagság kötelező adatszolgáltatásához, igen magas árbevételhez - a végleges elismeréshez 150 milliós, az előzetes elismeréshez 60 milliós éves árbevétel szükséges kötött, ugyanakkor a tagoknak kötelezniük kell magukat arra, hogy azt a terméküket, amelyre a TÉSZ alakult, 100, illetve megengedhetően 75\%-ban a szervezeten keresztül értékesítik. A termelőket a kötelező adatszolgáltatás és a kötelező értékesítés egyaránt elriasztja. A jelenlegi támogatási rendszer a TÉSZ-ek megalakítását, az adott feltételek teljesülése esetén 30 millió Ft-tal támogatja, ugyanakkor a termékpályás szövetkezetek számára - amelyeknek nem kell a TÉSZ-ekhez hasonló feltételeknek megfelelniük - 15 millió Ft-os, vissza nem térítendő támogatást biztosít. Ilyen körülmények között, s mert a termelök - alább ismertetendő okok miatt nem tudják a feltételeket teljesíteni, érthető, ha a régióban megalakult termelöi szervezetek nem TÉSZ-ként, hanem beszerzö és értékesitési szövetkezetként (BÉSZ) kerültek bejegyzésre. A szövetkezetek megalakulásában kétségtelenül fontos szerepet játszott az állami támogatási források megszerzésének lehetősége - noha akad termelö, aki szerint az állami támogatás legfeljebb amolyan szociális segélyként fogható fel, és csak mondvacsinált szövetkezést eredményez, a valódi problémákat nem oldja meg. 


\section{Akadozó kooperáció: termelői szövetkezetek a régióban ${ }^{16}$}

Az új termelői kooperációk között a leggyakrabban azokkal a szövetkezetekkel találkozhatunk, amelyek egy-egy, a helyi társadalomban köztiszteletnek örvendő, sikeres vállalkozó/családi vállalkozás kezdeményezésére alakultak meg, amelyekben horizontális kapcsolatok füzik egymáshoz a zöldségkertész családi vállalkozásokat. E társulásoknál a taggá válás feltétele nem ritkán egy olyan mennyiségi bekerülési küszöb (föld, gépkapacitás, egyéb termelői kapacitás, stb.), amely feltételez egy meghatározott tőkeerőt, azaz eleve kizárja a kevésbé életképesnek tekintett termelői csoportokat, akik nem tudnának megfelelni a mennyiségi és minőségi elvárásoknak. Az igazán jelentős, sikeres termelők számára pedig egyáltalán nem vonzó a korlátozások egész sorával járó szövetkezés és a közös értékesítés, hisz bejáratott piaci kapcsolatokkal rendelkeznek. Ezek a szövetkezetek tehát döntően a közepes méretü családi gazdaságokra, vállalkozásokra szerveződnek, s szinte kizárólag települési szintű együttműködésekre korlátozódnak. E szervezetek elsődleges feladatuknak új piaci csatornák felkutatását tartják. Nem egy esetben azonban belső feszültséget, bizalmatlanságot okoz, sőt, akár müködésképtelenséget is eredményezhet a potyautas-jelenség, hogy ti. a tagok (az előzetes, szóbeli megállapodással ellentétben) nem engedik be saját piacaikra a szövetkezetet, viszont elvárják, hogy az új piacokra a szövetkezet bevigye öket.

Közös jellemzője e szervezeteknek az átfogó tőkehiány, ami nem csupán az integrációs tevékenység bővítését, a szükséges fejlesztéseket korlátozza, de a mindennapi müködést is megnehezíti. Kizárólag a tag-gazdaságok által befizetett részjegy és a hozzájárulás képezi a szövetkezet müködésének anyagi hátterét, ám némely esetben a müködési hozzájárulás beszedésére tett erőfeszítések is kudarcot vallanak. A tőkehiány nem teszi lehetővé a szövetkezetek számára a piackeresést, logisztikai feladatok ellátását végző szakember alkalmazását sem. Ebben a helyzetben általában a szövetkezetek egy-egy olyan tagja vállalja magára a fenti feladatokat, aki jól bevált értékesítési csatornákkal, kamatoztatható kapcsolatrendszerrel rendelkezik, s általában saját forrásaiból, jobb esetben részben szövetkezeti forrásból fedezi a feladattal járó költségeket.

Nem ritka, hogy a hiányos értékesítési csatornákkal jellemezhető termelöi szervezetek mellé kiterjedt piaci kapcsolatrendszerrel rendelkező, erős gazdasági társaságok szegődnek, ezek tulajdonosai tagként (néha vezetőként) kötődnek a szervezethez, ugyanakkor felvásárlóként lépnek fel vele szemben. A két szerep az eltérō érdekeltségből adódóan nehezen összeegyeztethető, hiszen míg a termelő a termék árának maximalizálásában, addig a felvásárló annak leszorításában érdekelt. Egy kisebb vállalkozást irányító kertész véleménye szerint - a településen az újonnan alakult szövetkezet és a legnagyobb felvásárló cég vezetője egyazon személy -, ilyen esetekben a haszon maximalizálása előbbre való, mint a szolidaritás: „úgy viselkednek, mint bármelyik nepper a nagybanin”.

Az értékesítési szövetkezetek vezetői pontosan tudják, a jelenlegi szervezeti forma csupán az első lépés a termelők valódi integrációja és a valóban sikeres fellépés 
irányába, és a TÉSZ-szé alakulást tartják kívánatosnak. Ám a tőkehiány mellett $a$ belső konfliktusok is nehezítik a továbblépést. A szövetkezetek müködésének és a TÉSZ-szé alakulásnak is elemi feltétele a tagok aktív közreműködése, vagyis az adatszolgáltatás a termőterületröl, várható termésmennyiségröl, ám a tagok ódzkodnak attól, hogy gazdaságukat átláthatóvá és ellenőrizhetővé tegyék. A termelői szervezetek nem, vagy csak korlátozottan érvényesítik tagjaikkal szemben az adatszolgáltatással és a szervezeten keresztül történő kötelező értékesítéssel összefüggő szerepüket. Így általában nem is határozzák meg a tagok által beszállítandó termés mennyiségét, arra törekszenek, hogy a támogatáshoz szükséges árbevételt elérjék, ez azonban néha csak úgy sikerül, hogy a szervezethez nem tartozó termelőktől is felvásárolnak árut. Csak egy-két szövetkezetben tettek kísérletet arra, hogy meghatározzanak egy kötelezö, a szövetkezeten keresztül értékesítendő forgalmat, ügyelve arra, hogy az őstermelőként müködő vállalkozók az adómentes jövedelem határán belül maradjanak. A tagok gyakorlatilag továbbra is több csatornán keresztül értékesítik tehát termékeiket, sokuk számára a szövetkezet amolyan biztonsági hálóként müködik, s jellemző az a stratégia is, hogy a kurrens termékeket (pl. a szamócát) egyénileg, a nagybani piacon, míg a tömegárut a szövetkezeten keresztül adják el.

Ám nem pusztán a tagok óvatos és bizalmatlan piaci magatartása korlátozza az árualap s így a forgalom növelését. A szövetkezeteknek egyfelöl nem áll semmilyen eszköz rendelkezésre ahhoz, hogy a szervezet érdekeit érvényre juttassák tagjaikkal szemben, másfelöl maguk sem rendelkeznek megfelelö háttérkapacitással (telephelyek, hütőházak ${ }^{17}$ és stabil piaci csatornákkal ahhoz, hogy a tagjaik által beszállitott teljes árumennyiséget elhelyezni és értékesiteni tudják. Ez a bizonytalansággal jellemezhető helyzet rontja a szövetkezetek piaci pozícióját is. A térségben müködő egyik jelentős kereskedő cég - a vállalkozás az országban müködő nagy TÉSZekkel áll kapcsolatban - vezetője szerint a termelői szervezetek nem tekinthetők megbízható beszállítóknak, mert a felvásárlóval szemben tett ígéretük telesítése attól függ, tagjaiktól sikerül-e beszerezni a kívánt mennyiséget - a kereskedőnek viszont időben el kell indítania az export-árut szállító kamionjait.

Az adott szervezeti forma belső döntési mechanizmusai is feszültség forrását jelenthetik. Az értékesítési szövetkezetekben az egy tag=egy szavazat elve érvényesül, de a tagok nem egyenlö mértékben értékesítenek a szövetkezeten keresztül, és különösen akkor válik feszítővé ez az ellentmondás, amikor egy közös beruházáshoz is különböző nagyságú összeggel járulnak hozzá. Érthető, racionális a szövetkezetek vezetőinek azon elképzelése, hogy a majdani TÉSZ-t nem szövetkezetként, hanem gazdasági társasági formában müködtetik, hiszen ott a tagok a megtermelt értékkel arányos mértékben vehetnek részt a szervezetet érintő fontos (pl. beruházási) döntésekben.

Nem jelentkeznek a belső konfliktusok azokban a kis számban ${ }^{18}$ megalakult termelöi társulásokban, amelyek lényegében egy családi vállalkozás körül szervezödnek meg, szövetkezeti vagy más formában. Az egyik ilyen szövetkezetben a savanyítással foglalkozó családi vállalkozás integrálja a rokonokból, barátokból álló termelői kört, a szövetkezet tagjai a vállalkozás számára biztosítják a megfelelő, 
részben nyersen értékesített, részben feldolgozott árualapot. Abban, hogy ez a szövetkezet zökkenők nélkül müködik - a tagok kizárólag a szövetkezetnek értékesítenek -, a barátságon alapuló bizalmon túl meghatározó szerepet játszik az a tény, hogy a tagok, egyetlen kivétellel, mellékfoglalkozásként foglalkoznak zöldségtermesztéssel, s a szövetkezet leveszi vállukról a piackeresés és értékesítés minden terhét.

A régióban megalakult termelői kooperációk sajátos, döntően a gyümölcságazatban ${ }^{19}$ megtalálható körét alkotják a tőkeerös, tipikusan nagyüzemi háttérből induló, bejáratott piaci csatornákkal rendelkező szervezeti tömörülések, összetett, egymáshoz többszörös tulajdoni és piaci érdekekkel kapcsolódó, társas vállalkozásokat és értékesítő szövetkezeteket is tömörítő cégcsoportok. E cégcsoportok szándékuk szerint afféle területi koordinátorként az ágazat szereplöinek minél szélesebb körét kívánják integrálni; régiós (adott esetben ország-) határokat is túllépő szerepet játszanak a zöldség- és gyümölcstermesztésben, és nem alkalmazzák azt a fajta szelekciós szürőt, amit a közepes termelőkre szerveződő szövetkezeteknél a bekerülési küszöb kapcsán említettünk. Az integrációs törekvés hátterében az áll, hogy az érintett cégcsoportok saját feldolgozó-ipari cégük szükségleteit kívánják a beszállítói kapacitás bővítése révén fedezni, vagy piaci pozíciójukat a megnövekedett árualappal stabilizálni. Ugyanakkor az integráció révén kétségtelenül leszükíthető a konkurensek tábora, s monopolizálható az ágazat termelői fölötti irányítás joga. E társulások struktúráját a vertikális kapcsolatok túlsúlya jellemzi, az integrációt kezdeményezö és megvalósitó gazdasági társaság (ritkábban szövetkezet) megőrzi a résztvevökkel szembeni koordinációs és gazdasági fölényét

\section{Perspektívák: a termelök önkéntes kooperációi a piacon}

A zöldség- és gyümölcstermesztő szövetkezetekben összességében lazának mondható az integráció, a kooperáció jószerivel kizárólag az értékesitésre szoritkozik, s az esetek többségében kiaknázatlanok a szervezeti keretekben rejlő más lehetőségek. Az értékesítés mellett néha a közös (vetőmag, palánta, mütrágya, vegyszer stb.) beszerzésre, elvétve nagyobb infrastrukturális fejlesztésekre (telephely, hütőház, manipuláló helyiség kialakítása, ültetvénytelepítés) találunk példát.

Az említett cégcsoportokon kívül, amelyek közvetlen beszállítói kapcsolatokkal is rendelkeznek, egyelőre, akárcsak a termelők, a termelői szervezetek, szövetkezetek is közvetítőkön keresztül jutnak el a fontos piacokra, áruházláncokba, exportpiacokra; ezek a szervezetek nem szállítanak közvetlenül a nagybani piacra. Mindaz, amit a termelök és a kereskedők közötti kapcsolatról elmondtunk, az új szervezetekre is érvényes; a kapcsolatokat nem írásbeli szerződés alapján szervezik, legfeljebb a beszállítandó mennyiséget és a körülbelüli árakat rögzítő, s döntően szóbeli megállapodásra kerül sor, itt is a személyes kapcsolatokon alapuló bizalom köré épül az értékesítés.

A régióban megalakult szövetkezetek, cégcsoportok együttmüködésére nem találunk példát, ebben akadályozza őket helyi beágyazottságuk, amely nem egyszer a 
belső együttmüködést is nehezíti; arra is van példa a régióban, hogy egy településen két, családi klánok köré szerveződött szövetkezet vetélkedik egymással. A zöldségés gyümölcstermesztő ágazatban jelenleg az egyes érdekcsoportok, termelői integrációk közötti verseny tanúi lehetünk; az egyes szövetkezetek, cégcsoportok igyekeznek megerősíteni pozíciójukat a térségben és gyakran azon kívül is. Ugyanakkor jelentôs versenytársakkal kell megküzdeniük. A nagybani piac, ha nem is közvetlenül, a legnagyobb konkurens, hiszen a feketén bonyolítható kereskedelemmel nehezen veheti fel a lépést a gazdálkodást és kereskedelmet egyaránt 'kifehérítő' értékesítő szövetkezet és a TÉSZ. Közvetlenebb veszélyt jelentenek azok a nagy, nem egyszer integrátori tevékenységet is folytató kereskedelmi vállalkozások, cégek, amelyek, szemben a termelők által alakított szövetkezetekkel, nem küszködnek az újonnan alakult szervezetek belső ellentmondásaival, nincsenek beágyazva a helyi társadalmakba, nem kötődnek egyetlen település vagy kistérség termelöihez sem. Mindenekelőtt azonban tőkeerejük az, ami eredményessé teheti őket a régióban. Megfogalmazott szándékaik szerint e szervezetek erösiteni kivánják pozícióikat, elsősorban a régió zöldség-termesztő vidékein, éspedig a térségben a helyi szintekröl induló kisebb integrátorok - felvásárló és értékesito" társas vállalkozások és új szövetkezetek - kiszoritása révén. Az új szövetkezetek versenyhátrányát jelentős mértékben növeli az a tény, hogy a müködöképességük fenntartásához és nélkülözhetetlen beruházásaikhoz szükséges állami források, a deklarált politikai szándék ellenére, igen szükösen csordogáltak az elmúlt években.

Mindez arra figyelmeztet, hogy az újonnan alakult, tőke és megfelelő infrastrukturális-logisztikai háttérkapacitás hiányával, belső konfliktusokkal és bizalmatlansággal küzdeni kénytelen termelöi szervezeteknek, szövetkezeteknek alig van esélyük arra, hogy árualapjukkal közvetlenül, a közvetítő kereskedelem kiiktatásával jelenjenek meg a hazai és export-piacon, s hogy az uniós csatlakozás idejére nem lesznek képesek arra, hogy versenyképes, az uniós támogatások fogadására alkalmas piaci szereplőkké váljanak.

\section{Jegyzetek}

${ }^{1}$ A Közép-magyarországi Regionális Fejlesztési Tanács megbízásából az MTA RKK valamint az AKII által alakított Agri-Lánc konzorcium beszállítói, feldolgozói és értékesítési programot készített el 2001-ben, a témafelelős Dr. Kovács Katalin volt.

21993 óta állami támogatással több, mint 4000 hektár gyümölcsöst telepítettek Pest megyében a termelők. Az állomány zöme meggy és szilva. Az új telepítések 39\%-a a Dél-Pest megyei gyümölcstermesztési tájkörzetben, a régió legjelentősebb gyümölcstermesztő vidékén koncentrálódott (Forrás: Fővárosi és Pest megyei FM-Hivatal 2001; A Dél-Pest megyei... 2000).

${ }^{3}$ A Galga-vidékről Egerbe és Mezőkövesdre járnak a termelők, Szolnok piacán megjelennek a Tápióság és Dél-Pest megye kertészei, az utóbbi térségből és Dabas környékéről Kecskemétre is hordják árujukat a gazdálkodók.

${ }^{4}$ Turán pl. olyan napi piac müködik, ahol a nagybanin állandó hellyel rendelkező termelők vásárolják föl a kisebb gazdaságok áruját. Sokan szállítanak a vecsési savanyítóknak is zöldséget.

${ }^{5}$ Meg kell említenünk az elsősorban a gyümölcságazatban jelentkező problémát, hogy ti. a balkán háborúk kedvezően befolyásolták a hazai termékek nyugati piacát és árait, a helyzet konszolidálódását követően azonban romlottak a magyar termelők pozíciói. 
${ }^{6}$ Hantó Zsuzsa idézi a termelői véleményt, miszerint a termelést és nem az integrációt kellene támogatni, mert az integrátorok lefölözik a termelöknek juttatandó támogatást, és az általuk biztosított szolgáltatások, forgóeszköz-hitel fejében alacsonyra szorított árakon veszik át az integrált termelök áruját.

7 1080/1997. Kormányhatározat az agrártermelési integrációról. Az Integrált Termelésszervezési Rendszerek (ITR) szervezése az 1995-ös Agrármodernizációs Program keretében indult meg.

${ }^{8}$ Az FVM Fővárosi és Pest megyei Földművelésügyi Hivatal információja. 1998-ban nyílt lehetőség integrátori bejegyzésre, azóta 17 integrátor vonta vissza bejelentkezését. Az integrátori szerep vonzerejét csökkentette, hogy míg 1998-ban az integrátorok beruházásaikhoz is támogatást kaptak, azóta 'csak' forgóeszköz hitelhez juthatnak hozzá.

9 1990-ben összesen 8 ezer tonna volt a hazánkban előállított gomba mennyisége, 2000-ben már elérte a 38 ezer tonnát. Míg 1990-ben a gomba 9\%-át exportálták, addig az export aránya az ágazatban 2000-ben már elérte a 44\%-ot. A gombaágazat termelési értéke 2000-ben 18 milliárd Ft volt, ezen belül a friss gomba exportja meghaladta a 6 milliárd forintot (Forrás: Magyar Gomba 1998; Magyar ZöldségGyümölcs Terméktanács 2000. évi információs jelentése).

10 Az eddig megvalósult, illetve a tervezett beruházások már Budapesten kívül valósulnak meg, a gombatermesztésben tehát a régión belüli eltolódás tanúi lehetünk.

11 A tájkörzet 2154 hektáros gyümölcsültetvény területéből 747 hektáron termesztenek bogyós gyümölcsöt. Az ültetvények 44\%-a málna, 56\%-a ribizli.

${ }^{12}$ A málnatermesztés a Vácduka-Rád vonalon fokozatosan a termőtáj Nógrád megyei területére húzódik át. Ebben, az említett okok mellett, nem kis szerepet játszik az a tény, hogy a szomszédos Nógrád megye termelöi - a hátrányos helyzetű besorolást 'élvező' megyének juttatott eszközöknek köszönhetően - az 55\%-os állami támogatás mellett a megyei területfejlesztési forrásokból is részesülhetnek, a telepítés költségeinek 75\%-át így állami eszközökből tudják fedezni. Nógrád megyében ültetvény-méretű telepítésekre került sor, és jelentős integrátori tevékenység bontakozott ki.

13 Helyzetüket nehezíti a bogyós gyümölcs rendkívüli érzékenysége; a szedés után néhány órán belül hűtő tárolóban kell elhelyezni, ilyen kapacitással azonban a termelők nem rendelkeznek, így, ha nem akarják, hogy nyakukon maradjon az áru, kénytelenek azt rögtön értékesíteni.

${ }^{14}$ EU 2200/96. sz. rendelet a gyümölcs- és zöldségtermelői szervezetekröl (producer's organization). A magyar szabályozáshoz lásd a 25/1999 (III.5.) számú rendeletet a zöldség, gyümölcs termelői értékesítő szervezetekről.

${ }^{15}$ Az országban összesen 12 előzetesen elismert TÉSZ müködik, közülük egy sem található a Középmagyarországi régióban. A jelentős forgalmú, több száz termelőt integráló TÉSZ-ek sem jutottak állami támogatáshoz müködtetésükre és beruházásaikra, 2000-ben leállították a megítélt támogatások kifizetését, 2001-ben a benyújtott pályázatok lassú elbírálása adott okot panaszra (Szabó 2001).

16 A megalakult beszerző és értékesítési szövetkezetek elhelyezkedése térbeli koncentrációt mutat, a fövárost övező zöldségtermesztő gyürü településein (Alsónémedi, Vecsés), valamint Dél-Pest megyében (Nagykőrös, Nyársapát, Tápiószőlős, Nyáregyháza) müködnek, azokban a térségekben, ahol az ágazat legtöbb szereplöje él, s ahol a zöldség-, gyümölcstermesztés hosszú távon is domináns ágazat és fontos megélhetési forrás marad.

17 A Zöldség- és Gyümölcs Terméktanács számításai szerint egy megfelelő technológiával és háttérrel fölszerelt hütő-csomagoló kapacitás megépítése úgy 600 millió forintba kerül (Zöldség-és Gyümölcspiac 2001).

18 Jellemzően a kiskunlacházi-ráckevei térségben alakultak ilyen szövetkezetek.

19 Dömsödön múködik egy olyan több szövetkezetből és társas vállalkozásból álló cégcsoport, amely más tevékenységek mellett zöldség termesztésével és szárításával is foglalkozik.

\section{Irodalom}

A Dél-Pest megyei gyümölcstermesztési tájkörzet stratégiai programja. (2000) Pest megyei Agrárkamara, Budapest.

Bali J. (1998) Megtorpanás? A mezőgazdasági árutermelés fejlődésének korlátai egy málnatermelő településen. - Replika. 33-34. 107-121. o.

Dr. Boldvainé dr. Böde Beáta interjúja dr. Lux Róberttel, a Zöldség- Gyümölcs Terméktanács főtitkárával. (2001) - Zöldség-és Gyümölcspiac. 10.

Gombaexport. (1998) - Magyar Gomba. 3. 
Hantó Zs. (1996) Integrációs változatok a magyarországi mezőgazdaságban. - Gazdálkodás. 6. 40-48. o. Juhász P.-Mohácsi K. (1995) Az agrárágazat támogatásának néhány összefüggése. - Közgazdasági Szemle. 5. 471-484. o.

Kapronczai I. (1996) Az egyéni termelés integrálása az agrárgazdaságban. - Gazdálkodás. 6. 49-54. o.

Kovács Cs.-Kovács K.-Bihari Zs. (1998) Az agrárgazdasági folyamatok térségi összefüggései a kilencvenes években. - Hamar A. (szerk.) Agrárátalakulás Magyarországon a kilencvenes években. I-II. Phare-KGF-RKK, Szolnok. 81-164. o.

Kovács K. (2001) A Közép-magyarországi Régió agrárgazdasága és agrártermelöi a számok tükrében. Háttértanulmány.

Szabó M. (2001) TÉSZ-tapasztalatok. - Zöldség- és Gyümölcspiac. 10. 10-12. o.

Tóth E.-Varga Gy. (1997) Az átalakult mezőgazdasági szövetkezetek helyzete és jövőbeni szerepe. Szövetkezés. 1-2. 85-97. o. 